\title{
Kecemasan dan Depresi pada Pasien Gagal Ginjal Kronis yang Menjalani Terapi Hemodialisis
}

\author{
Riselligia Caninsti \\ Fakultas Psikologi, Universitas YARSI \\ Jl. Letjen Suprapto, Cempaka Putih, Jakarta Pusat \\ riselligia.caninsti@yarsi.ac.id
}

\begin{abstract}
Chronic renal disease and hemodialysis therapy were performed 2-3 times a week, have an impact on the patient's psychological condition. The patient feels frustrated and give up on their life, so that they feel anxiety and depression, they are often able to accept the reality after the person was on the verge of death. In general, patients undergoing treatment in the hospital just to get medical treatment, while the psychological condition which one the reaction of the physical complaints or other factors that are the result of a perceived physical complaints often go unnoticed. This study aims to determine the psychological condition of patients, especially as related to anxiety and depression, through a measurement tool, which can be used by doctors, nurses, psychologists and other health professionals in the hospital setting. Measuring tool used is the Hospital Anxiety and Depression Scale (HADS), which has been designed for use in the hospital setting and is made up of 14 items. The application of HADS to patients, is expected to know the level of anxiety and depression of the patients, so that health care practitioners can provide appropriate treatment to solved patients' psychological problems. The results showed that 73.33\% subjects had relatively normal levels of anxiety, borderline abnormal $23.33 \%$, and $3.33 \%$ normal. While the depressed patients in the normal level as much as 76.67\%, 23.33\% borderline abnormal and no one categorized in abnormal depressed.
\end{abstract}

Keywords: anxiety; depression; renal failure; hemodialysis

\begin{abstract}
Abstrak-Penyakit gagal ginjal kronis dan terapi hemodialisis yang dilakukan 2-3 kali seminggu, membawa dampak pada kondisi psikologis pasien. Pasien merasa kecewa dan putus asa terhadap hidupnya sehingga mengalami kecemasan dan depresi, sering kali pasien baru dapat menerima kenyataan setelah yang bersangkutan berada di ambang kematian. Pada umumnya pasien yang menjalani pengobatan di rumah sakit hanya mendapatkan penanganan secara medis, sedangkan kondisi psikologis yang merupakan reaksi dari keluhan fisik atau faktor lain yang merupakan akibat dari adanya keluhan fisik yang dirasakan sering kali tidak diperhatikan. Penelitian ini bertujuan untuk mengetahui kondisi psikologis pasien, terutama yang terkait dengan kecemasan dan depresi melalui sebuah alat ukur yang dapat digunakan oleh Dokter, Perawat, Psikolog
\end{abstract}


dan praktisi kesehatan lainnya di setting rumah sakit. Alat ukur yang digunakan adalah Hospital Anxiety and Depression Scale (HADS) yang telah dirancang untuk digunakan dalam setting rumah sakit dan hanya terdiri dari 14 item. Dengan diaplikasikannya alat ukur HADS kepada pasien, diharapkan dapat diketahui tingkat kecemasan dan depresi pasien, sehingga praktisi kesehatan mampu memberikan pendampingan yang tepat untuk mengatasi permasalahan psikologis pasien. Hasil penelitian menunjukkan bahwa 73.33 \% subjek memiliki tingkat kecemasan yang tergolong normal, $23.33 \%$ borderline abnormal, dan $3.33 \%$ normal. Sementara itu pasien yang mengalami depresi dalam tingkat normal sebanyak $76.67 \%$, borderline abnormal $23.33 \%$ dan tidak ada yang mengalami depresi dalam kategori abnormal.

Kata kunci: kecemasan; depresi; gagal ginjal; hemodialisis

\section{PENDAHULUAN}

\section{Latar Belakang}

Gagal ginjal merupakan keadaan berkurangnya fungsi ginjal ke suatu kondisi yang apabila fungsi ginjal tidak kembali, akan mengakibatkan kerusakan total dari fungsi eksresi dan juga ancaman kematian. Gagal ginjal terjadi jika kedua ginjal milik seseorang mengalami kerusakan. Pada kondisi tersebut, ginjal tidak dapat menjalankan fungsinya mengeluarkan sisa metabolisme dan mempertahankan keseimbangan cairan dan garam dalam tubuh. Selain itu, ginjal yang rusak tidak dapat menjalankan fungsinya sebagai pembuat hormon yang bertugas ikut memelihara darah merah dan kesehatan tulang. Bila fungsi ginjal sudah sangat rendah, maka sisa metabolisme menumpuk, cairan menumpuk, mineral-mineral menumpuk, dan kondisi darah menjadi asam (asidosis). Kondisi ini mengakibatkan pasien mengeluh sesak napas, lemas, mual, dan kurang darah (anemia). Jika penumpukan sisa metabolisme ini tidak segera ditangani, maka hal ini akan sangat membahayakan pasien (Lumenta, 2003).

Peterson (1995) mengatakan bahwa terdapat dua jenis gagal ginjal, yaitu gagal ginjal akut dan gagal ginjal kronis. Dikatakan gagal ginjal akut bila penurunan fungsi ginjal berlangsung secara tiba-tiba, namun dapat kembali normal apabila penyebabnya ditanggulangi. Penyebab gagal ginjal akut diantaranya muntaber, pendarahan, keracunan obat dan sumbatan pada saluran kemih. Penderita gagal ginjal akut tidak diharuskan menjalani cuci darah seumur hidupnya, hanya seperlunya saja sekitar 1-2 kali. Pada kasus gagal ginjal akut, ginjal akan berfungsi normal bila pengeluaran urin sudah normal dan keadaan fisik sudah pulih. Sementara itu, gagal ginjal kronis merupakan keadaan di mana terjadinya penurunan fungsi ginjal secara perlahan. Penurunan fungsi ginjal dapat mencapai $60 \%$ dari kondisi normal, hal ini mengakibatkan kemampuan ginjal untuk mengeluarkan sisa metabolisme di dalam tubuh menjadi terganggu, sehingga terjadi penumpukan sisa metabolisme di dalam tubuh yang disebut dengan sindrom uremik.

Soehardjono (2006) berpendapat bahwa penyakit gagal ginjal kronis dapat digolongkan sebagai stressor, yaitu peristiwa yang menimbulkan stres pada seseorang. Pasien yang menjalani terapi hemodialisis pada umumnya mengalami stres. Berkaitan dengan definisi stres, Baum (dalam Taylor, 1999) mengatakan bahwa stres merupakan pengalaman emosi negatif yang diiringi oleh perubahan biokimia, fisik, kognitif dan perilaku yang mengarahkan individu untuk mengubah kondisi yang menimbulkan stres (stressful event) atau menyesuaikan diri dengan akibat yang ditimbulkan oleh stressfull event tersebut. 
Pasien gagal ginjal kronis yang menjalani terapi hemodialisis berfikir bahwa agar dapat bertahan hidup ia akan selalu memiliki ketergantungan terhadap mesin dialisis. Hal ini sering kali menimbulkan pemikiran dalam diri pasien bahwa nyawanya akan terancam dan harapan untuk hidup semakin berkurang, pasien mengalami ketakutan bahwa usianya tidak lama lagi, dan permasalahan ini juga menimbulkan konflik dalam keluarga.

Pasien gagal ginjal kronis yang menjalani terapi hemodialisis sebenarnya bisa bertahan hidup lebih lama. Menurut Roesli (2006) di antara pasien ada yang sudah menjalani hemodialisis selama 15-20 tahun. Keberhasilan tidak hanya didukung oleh perawatan secara medis, tetapi juga oleh penyesuaian diri pasien terhadap kondisi sakit yang dideritanya. Perasaan cemas yang dirasakan pasien saat menjalani terapi hemodialisis memang sering ditemukan, namun sebenarnya pasien tidak perlu merasa risau karena dengan menjalani pengobatan, olahraga dan diet dengan teratur, maka mereka dapat menjalani aktivitasnya dengan normal.

Beck, Amery \& Greenberg (Freeman \& DiTomasso dalam Wolman \& Stricker, 1994) mengemukakan bahwa dari sudut pandang kognitif (cognitive model), terdapat 5 kemungkinan faktor predisposisi atau faktor yang secara potensial dapat menyebabkan individu mengalami kecemasan, diantaranya:

1. Genetic inheritability (pewarisan genetis)

Faktor hereditas mempengaruhi mudah tidaknya saraf otonom menerima rangsang. Dengan kata lain, seseorang dengan sejarah keluarga yang memiliki gangguan dalam kecemasan cenderung lebih menampakkan kecemasan bila dihadapkan pada situasi yang mencemaskan.

2. Physical disease states (penyakit fisik)

Pandangan kognitif mengatakan bahwa faktor penyakit fisik dapat membuat individu mengalami kecemasan.

3. Psychological trauma/mental trauma (Trauma Mental)

Individu akan menjadi lebih mudah cemas ketika ia dihadapkan pada situasi yang serupa dengan pengalaman terdahulu yang menimbulkan trauma, di mana situasi tersebut seperti skema yang telah dipelajari.

4. Absence of coping mechanisms (tidak adanya mekanisme penyesuaian diri)

Individu yang mengalami kecemasan sering menunjukkan defisit dalam respon-respon penyesuaian diri terhadap kecemasan itu sendiri. Mereka merasa tidak berdaya untuk menemukan strategi dalam mengatasi kecemasan tersebut. Akibatnya individu membiarkan diri mereka berada dalam situasi yang secara potensial dapat membuat mereka cemas.

5. Irrational thoughts, assumptions and cognitive processing errors. (pikiran-pikiran irasional, asumsi dan kesalahan proses kognisi)

Pada individu yang memiliki gangguan kecemasan, keyakinan yang tidak realistik / keyakinan semu mengenai suatu ancaman atau bahaya dianggap dipicu oleh situasi-situasi tertentu yang mirip dengan situasi ketika keyakinan semu tersebut dipelajari. Jika skema keyakinan semu tersebut teraktifkan, skema ini dapat mendorong pikiran, tingkah laku dan emosi orang tersebut untuk masuk dalam keadaan cemas.

Selain faktor predisposisi kecemasan, Freeman dan DiTomasso (dalam Wolman \& Stricker, 1994) mengungkapkan bahwa terdapat beberapa faktor pencetus kecemasan, yaitu:

1. Masalah fisik yang dapat menyebabkan kelelahan sehingga mempengaruhi ambang toleransi individu dalam menghadapi stressor dalam kehidupan sehari-hari. 
2. Stressor eksternal yang berat seperti kematian orang yang dicintai atau kehilangan pekerjaan.

3. Stressor eksternal yang berkepanjangan dan berlangsung dalam jangka waktu yang lama sehingga membuat usaha coping individu menjadi lemah.

4. Kepekaan emosi, di mana sesuatu yang menimbulkan kecemasan pada seseorang belum tentu memiliki pengaruh yang sama pada orang lain.

Berdasarkan penjelasan di atas, diketahui bahwa kondisi fisik seperti keadaan sakit yang dialami individu dan stressor eksternal yang berat dan berkepanjangan merupakan faktor yang dapat menimbulkan kecemasan pada seseorang. Pada kondisi ini, pasien perlu diarahkan untuk mengeluarkan respon-respon yang tepat dalam menghadapi stres, sehingga ia dapat menyesuaikan diri dengan kondisinya, misalnya dengan terus menjalani pengobatan. Hal yang penting untuk dihindari adalah respon-respon yang dapat memperburuk situasi sehingga menimbulkan akibat yang lebih fatal, seperti munculnya gejala depresi.

McDowell dan Newell (1996) mengungkapkan bahwa depresi adalah bentuk afek dan merupakan kondisi universal yang dapat dialami oleh manusia, mulai dari perubahan mood yang normal sampai dengan keadaan yang patologis. Downing Orr (2000), mengatakan bahwa kondisi depresi terbagi menjadi dua, yaitu:

1. Perasaan depresi yang normal, yaitu perasaan sedih dan frustasi yang tidak menetap yang merupakan respon dari adanya suatu peristiwa atau kesulitan tertentu yang memunculkan rasa disakiti, pesimis, maupun tidak berdaya.

2. Depresi klinis. Pada kondisi ini, dengan ada atau tidaknya peristiwa pemicu, seorang individu mengalami perasaan tertekan yang parah, menetap dan merasa seluruh bentuk dukungan dari orang lain tidak membuatnya nyaman; merasa terisolasi; merasakan bahwa masa depannya pasti suram, menyakitkan dan menyedihkan, individu tidak mampu untuk melihat sisi baik dan optimisme dunia, di mana perasaan-perasaan tersebut seolah-olah menjadi bagian dari sifat-sifat kepribadiannya.

Downing Orr (2000) juga menambahkan bahwa akan sulit untuk membedakan kedua kondisi depresi tersebut secara jelas karena keduanya sama-sama menyebabkan atau disebabkan oleh penyakit fisik seseorang.

Tidak mudah bagi seseorang jika dihadapkan pada kenyataan bahwa dirinya mengalami penyakit gagal ginjal kronis dan harus menjalani terapi hemodialisis selama sisa hidupnya. Penyakit gagal ginjal kronis dan terapi hemodialisis ternyata membawa dampak pada kondisi psikologis pasien, selain perasaan cemas, pasien juga dapat mengalami depresi, namun hal ini tampaknya kurang menjadi perhatian bagi para dokter ataupun perawat. Pada umumnya, pasien yang menjalani pengobatan di rumah sakit hanya mendapatkan penanganan secara medis. Pengobatan yang dilakukan difokuskan pada pemulihan kondisi fisik tanpa memperhatikan kondisi psikologis pasien. Snaith (2003) mengatakan bahwa seorang dokter yang menghadapi pasien yang dari segi fisik menderita suatu penyakit, pada umumnya hanya berkonsentrasi untuk menangani keluhan fisik yang dirasakan pasien, namun kondisi psikologis yang merupakan reaksi dari keluhan fisik tersebut atau faktor lain yang merupakan akibat dari adanya keluhan fisik yang dirasakan individu sering kali tidak diperhatikan.

Para praktisi kesehatan menyadari bahwa kondisi psikologis pasien bisa mempengaruhi kesehatan fisiknya. Keterbatasan para praktisi kesehatan dalam menggali kondisi psikologis yang dirasakan pasien menjadi salah satu alasan perlunya suatu metode yang sederhana untuk mengetahui kondisi psikologis dalam setting klinis yang nantinya dapat membantu dokter, perawat, psikolog dan praktisi kesehatan lainnya saat berhadapan dengan pasien. Informasi mengenai kondisi psikologis yang dirasakan pasien dapat diperoleh dengan menggunakan kuisioner yang diisi oleh pasien berdasarkan pengalamannya sehingga membantu 
para praktisi kesehatan dalam memberikan penanganan yang tepat kepada pasien. (Shepherd dkk, dalam Snaith 2003).

Berdasarkan keterangan di atas, maka diperlukan suatu upaya agar data yang diperoleh lebih terfokus pada kondisi psikologis pasien rumah sakit. Metode yang banyak digunakan adalah kuisioner, salah satu diantaranya yaitu alat ukur Hospital Anxiety and Depression Scale (HADS) yang telah dirancang untuk digunakan dalam setting rumah sakit dan hanya terdiri dari 14 item. HADS terdiri dari dua subskala, yaitu anxiety (kecemasan) dan depression (depresi). Item-item dalam HADS terdiri dari 7 item berhubungan dengan anxiety (kecemasan) dan 7 item lainnya berhubungan dengan depression (depresi). Dengan menggunakan HADS, diharapkan pasien dapat lebih mudah memberikan respon sesuai dengan kondisi yang ia rasakan, sehingga dapat diketahui tingkat kecemasan dan depresi pasien. Alat ukur HADS yang semula menggunakan bahasa Inggris akan diterjemahkan terlebih dahulu ke dalam bahasa Indonesia.

\section{Pertanyaan Penelitian}

Pertanyaan dalam penelitian ini adalah: Bagaimana tingkat kecemasan dan depresi pada pasien gagal ginjal kronis yang menjalani terapi hemodialisis, menurut alat ukur Hospital Anxiety and Depression Scale?

\section{Tujuan Penelitian}

Mengetahui tingkat kecemasan dan depresi pasien gagal ginjal kronis yang menjalani terapi hemodialisis, melalui alat ukur Hospital Anxiety and Depression Scale .

\section{Manfaat Penelitian}

1. Hasil penelitian ini diharapkan dapat dijadikan rujukan atau bahan kajian bagi usaha-usaha pembahasan selanjutnya. Penelitian ini juga diharapkan dapat memberikan sumbangan pada kajian ilmiah psikologi khususnya Psikologi Kesehatan.

2. Alat ukur Hospital Anxiety and Depression Scale yang telah diterjemahkan ke dalam Bahasa Indonesia dapat digunakan oleh praktisi kesehatan untuk mengetahui tingkat Kecemasan dan Depresi pasien hemodialisis.

3. Hasil penelitian yang diperoleh, diharapkan dapat memberikan informasi kepada masyarakat, khususnya para pasien gagal ginjal kronis yang menjalani terapi hemodialisis bahwa kondisi psikologis seperti kecemasan dan depresi kemungkinan besar dapat memperburuk kondisi fisik dan psikologisnya. Dengan informasi yang diberikan, diharapkan para penderita Gagal Ginjal Kronis (GGK) yang sedang menjalani terapi hemodialisis tidak bersikap pesimis terhadap kondisinya dan terhindar dari perasaan cemas yang berlebihan dan depresi, sehingga mau melakukan langkah-langkah untuk menjaga kesehatan fisik dan psikologisnya agar berada dalam kondisi yang stabil. 


\section{METODE}

\section{Partisipan}

Subjek penelitian ini adalah pasien gagal ginjal kronis yang sedang menjalani terapi hemodialisis. Subjek yang akan menjadi sampel dalam penelitian ini adalah individu yang memenuhi kriteria sebagai berikut:

1. Pasien gagal ginjal kronis dan sedang menjalani terapi hemodialisis.

Pasien yang sedang menjalani terapi hemodialisis, diasumsikan telah merasakan dampak dari proses hemodialisis terhadap kondisi fisik, psikologis serta pengaruhnya dalam melakukan aktivitas seharihari.

2. Usia 15-65 tahun.

Rentang usia ini disesuaikan dengan fungsi alat ukur HADS. HADS bertujuan untuk melihat tingkat kecemasan dan depresi pada subjek yang berusia antara 15-65 tahun.

3. Pasien sedang menjalani terapi hemodialisis, namun tidak dalam kondisi rawat inap.

Subjek diharapkan dalam kondisi yang dianggap mampu untuk menjalani prosedur penelitian. Pasien rawat inap diasumsikan masih dalam kondisi yang belum stabil.

4. Berpendidikan minimal SMA atau setara

Latar belakang pendidikan minimal SMA, bertujuan agar subjek dapat memahami maksud dari pertanyaan-pertanyaan yang ada dalam alat ukur yang digunakan oleh peneliti.

Teknik pengambilan sampel. Pada penelitian ini, untuk mendapatkan sampel yang dituju maka subjek penelitian diambil berdasarkan metode non probability sampling, yaitu purposive sampling. Dalam teknik ini, pemilihan sampel tidak dilakukan secara acak, Individu yang diikutsertakan dipilih karena memiliki kriteria sebagaimana yang telah ditentukan, sehingga tidak semua anggota populasi memperoleh kesempatan yang sama untuk dipilih sebagai subjek penelitian. Individu yang telah memenuhi kriteria yang ditetapkan diminta kesediaannya untuk menjadi subjek penelitian.

\section{Desain}

Penelitian ini menggunakan pendekatan kuantitatif. Pendekatan kuantitatif dilakukan dengan menggunakan Hospital Anxiety and Depression Scale (HADS) yang telah diterjemahkan ke dalam Bahasa Indonesia. Hal ini bertujuan untuk memperoleh gambaran mengenai tingkat kecemasan dan depresi pada pasien gagal ginjal kronis yang menjalani terapi hemodialisis.

\section{Prosedur}

Instrumen pengumpulan data. Pengambilan data dalam penelitian ini akan dilakukan dengan menggunakan Hospital Anxiety and Depression Scale (HADS). Hospital Anxiety and Depression Scale (HADS) dikembangkan oleh Zigmond \& Snaith pada tahun 1983. HADS merupakan self-report rating scale yang terdiri dari 14 item dan tersusun dalam bentuk kuisioner. HADS didesain dan digunakan untuk melihat kondisi psikologis terutama kecemasan dan depresi pada individu yang menderita sakit dan menjadi pasien 
di rumah sakit. Dengan kata lain, skala ini pada awalnya dikembangkan untuk melihat kecemasan (anxiety) dan depresi (depression) pada pasien Rumah Sakit yang memiliki dua permasalahan sekaligus yaitu derita fisik dan psikis (somatic and mental problem). Skala ini dinilai cukup spesifik dan memiliki sensitifitas yang baik sebagaimana instrumen lainnya yang sama-sama mengukur sikap pasien terhadap dirinya (Hermann \& Bjelland dalam Mykletun \& Dahl, 2001).

HADS pada awalnya dirancang untuk membantu dokter dalam menggali kondisi emosi pasien yang dirawat ataupun menjalani pengobatan di Rumah Sakit. Oleh karena itu metode yang dianggap paling efektif untuk digunakan adalah kuisioner dengan administrasi yang cepat dan mudah, dapat diterima oleh pasien dan tidak terpengaruh oleh simptom-simptom penyakit fisik (Lenze, dkk, dalam Mykletun \& Dahl, 2001). Untuk menghindari pengaruh atau efek yang tidak diinginkan dari simptom-simptom penyakit fisik, pada HADS tidak dimasukkan item-item yang berhubungan dengan keluhan fisik atau somatic items (Mykletun \& Dahl, 2001).

Zigmond \& Snaith (dalam Desmond \& McLachlan, 2005) mengungkapkan bahwa dalam mengembangkan item HADS, simptom-simptom somatic yang berhubungan dengan kecemasan dan depresi (seperti, sakit kepala, pusing, dan insomnia) tidak dimasukkan dalam menyusun skala tersebut. Karena simptom-simptom somatic itu dinilai lebih mengacu pada keluhan fisik dibandingkan psikologis. HADS dapat digunakan pada pasien rumah sakit yang berusia antara 16-65 tahun.

HADS terdiri dari 2 subskala, yaitu anxiety (kecemasan) dan depression (depresi). Terdapat masingmasing 7 item pada setiap subskala. 7 item mewakili kecemasan dan 7 item lainnya mewakili depresi. Sehingga total keseluruhan item adalah 14. Skor yang diperoleh pada masing-masing subskala berkisar antara 0-21. (Zigmond \& Snaith dalam Flint \& Sandra, 2002).

Zigmond \& Snaith (dalam Flint \& Sandra, 2002) mengungkapkan bahwa pada subskala depression (depresi), pernyataan atau item difokuskan pada konsep anhedonia, yaitu kehilangan minat untuk melakukan aktivitas yang menyenangkan. Sedangkan pada subskala anxiety (kecemasan), difokuskan pada aspek emosi dan kognisi dari anxiety. Tiga item berkaitan dengan perasaan takut atau panik dan empat item lainnya merupakan karakteristik dari kecemasan menyeluruh (generalized anxiety).

Tabel 1. Hospital Anxiety and Depression Scale

\begin{tabular}{|c|c|}
\hline Subskala & Contoh Item \\
\hline Kecemasan & $\begin{array}{l}\text { 1. Saya merasa takut bahwa sesuatu yang buruk akan terjadi } \\
\text { 2. Hal-hal yang mencemaskan terlintas dalam pikiran saya } \\
\text { 3. Di saat gugup atau khawatir, perut saya terasa mulas }\end{array}$ \\
\hline Depresi & $\begin{array}{l}\text { 1. Saya kehilangan minat terhadap penampilan saya } \\
\text { 2. Saya dapat tertawa dan melihat sisi yang menyenangkan dari setiap hal } \\
\text { 3. Saya merasa seolah-olah saya tidak bersemangat }\end{array}$ \\
\hline
\end{tabular}

Analisis Validitas dan Reliabilitas Sub skala Kecemasan. Item-item dalam sub skala kecemasan ini melihat derajat kecemasan di mana individu merasa takut atau khawatir akan hal-hal buruk yang akan menimpa dirinya serta adanya hal-hal yang mencemaskan terlintas di dalam pikirannya. Kecemasan tersebut juga membuat individu merasa panik dan tidak dapat merasa tenang atau santai. Selain itu ada pula item yang melihat derajat kecemasan individu melalui apakah ada pengaruh kecemasan terhadap kondisi fisiknya. Seperti contoh, disaat individu merasa takut atau khawatir maka perutnya akan terasa mual. Dalam hal ini, kecemasan yang dirasakan berhubungan dengan pengalaman individu sebagai pasien di rumah sakit. 
Hasil Analisis Validitas Item. Hasil uji validitas skala dalam penelitian ini menggunakan pendekatan construct validity melalui teknik internal consistency (yakni validitas dicari dengan melihat homogenitas item tes dengan menggunakan kriteria berupa skor tes itu sendiri) dengan menggunakan rumus corrected item-total correlation (Nunnaly \& Bernstein, 1994). Cronbach (1984) menyatakan bahwa biasanya koefisien validitas yang baik berkisar antara 0.2-0.6, dan jarang yang mencapai nilai $>0.6$. Sedangkan Nunnaly (dalam Nunnaly \& Bernstein, 1994) menjelaskan bahwa nilai item-total correlation yang baik adalah $\geq 0.3$, dengan nilai $r \geq 0.3$ diharapkan koefisien alpha menjadi lebih tinggi $(a=0.8-0.9)$.

Berdasarkan hasil perhitungan SPSS, diperoleh hasil bahwa dari 7 item yang ada pada sub skala kecemasan, keseluruhan item menunjukkan nilai corrected item total correlation yang lebih besar dari $0.3(\mathrm{r} \geq$ 0.3). Oleh karena itu, dapat disimpulkan bahwa keseluruhan item pada sub skala kecemasan tergolong valid.

Tabel 2. Hasil Perhitungan Validitas Sub Skala Kecemasan

\begin{tabular}{|c|c|}
\hline Item & $\begin{array}{c}\text { Corrected item-total } \\
\text { correlation }\end{array}$ \\
\hline Saya merasa tegang atau ingin marah & 0.4798 \\
\hline $\begin{array}{l}\text { Saya merasa takut bahwa } \\
\text { sesuatu yang buruk akan terjadi }\end{array}$ & 0.4827 \\
\hline Hal-hal yang mencemaskan terlintas dalam pikiran saya & 0.4709 \\
\hline Saya bisa duduk dengan senang dan merasa tenang / santai & 0.5014 \\
\hline $\begin{array}{l}\text { Di saat gugup atau khawatir, } \\
\text { perut saya terasa mulas }\end{array}$ & 0.5710 \\
\hline $\begin{array}{l}\text { Saya merasa tidak pernah lelah saat saya harus melakukan } \\
\text { sesuatu }\end{array}$ & 0.3094 \\
\hline Saya tiba-tiba merasa panik & 0.3972 \\
\hline
\end{tabular}

Hasil Analisis Reliabilitas Item. Uji reliabilitas dilakukan dengan menggunakan perhitungan rumus koefisien Alpha Cronbach. Menurut Anastasi dan Urbina (1997), jika indeks reliabilitas suatu tes berada pada rentang 0.8 - 0.9, maka tes tersebut dapat dikatakan reliabel, sedangkan menurut Kaplan dan Saccuzzo (1993) koefisien reliabilitas yang berada di antara 0.7-0.8 sudah cukup baik untuk kebanyakan tujuan penelitian. Oleh karena alat ukur Hospital Anxiety and Depression Scale ini digunakan dalam rangka penelitian, maka indeks reliabilitas yang digunakan adalah berdasarkan Kaplan dan Saccuzzo (1993).

Dari uji reliabilitas sub skala kecemasan, yang terdiri dari 7 item diperoleh hasil sebesar 0.7382. Hasil ini menunjukkan bahwa alat ukur dalam sub skala ini memiliki reliabilitas yang cukup baik. Dengan demikian, dapat dikatakan bahwa sub skala ini mengukur domain kecemasan, di mana individu merasa khawatir akan hal-hal buruk yang akan menimpanya terutama yang berkaitan dengan posisi individu sebagai pasien rumah sakit yang sedang menjalani terapi hemodialisis.

Analisis Validitas dan Reliabilitas Sub skala Depresi. Item-item dalam sub skala ini melihat derajat depresi pada masing-masing individu. Item-item tersebut mewakili konsep anhedonia, di mana individu kehilangan minat untuk melakukan aktivitas-aktivitas yang menyenangkan. Menurut Snaith (2003) hal ini merupakan salah satu indikator dari major depresive disorder.

Hasil Analisis Validitas Item. Uji validitas konstruk dilakukan melalui teknik internal consistency dengan menggunakan rumus corrected item-total correlation (Nunnaly \& Bernstein, 1994). Karena nilai $r$ yang digunakan berdasarkan pendapat yang dikemukakan oleh Nunnaly, di mana nilai item-total correlation 
yang baik adalah $\geq 0.3$, maka sebuah item dalam sub skala depresi ini dinilai valid atau tidak, baik atau buruk, apabila skor $r$-nya sama dengan atau lebih besar dari $0.3(\mathrm{r} \geq 0.3)$.

Berdasarkan hasil perhitungan SPSS, diperoleh hasil bahwa dari 7 item yang ada dalam sub skala ini, seluruh item menunjukkan nilai yang valid. Dengan demikian, dapat dikatakan bahwa seluruh item mengukur domain yang sama dengan sub sakala tersebut.

Tabel 3. Hasil Perhitungan Validitas Sub Skala Depresi

\begin{tabular}{lc}
\multicolumn{1}{c}{ Item } & $\begin{array}{c}\text { Corrected item- } \\
\text { total correlation }\end{array}$ \\
\hline Saya tetap menikmati hal-hal yang biasanya saya nikmati & 0.5464 \\
Saya dapat tertawa dan melihat sisi yang menyenangkan dari setiap hal & 0.4420 \\
Saya merasa gembira & 0.4915 \\
Saya merasa seolah-olah saya tidak bersemangat & 0.5513 \\
Saya kehilangan minat terhadap penampilan saya & 0.4512 \\
Saya menantikan dengan rasa senang hal-hal yang akan terjadi & 0.4667 \\
Saya dapat menikmati membaca buku, mendengarkan radio, atau & 0.4974 \\
menonton televisi & \\
\hline
\end{tabular}

Hasil Analisis Reliabilitas Item. Uji reliabilitas dilakukan dengan menggunakan perhitungan rumus koefisien Alpha Cronbach. Dari perhitungan yang dilakukan diperoleh hasil sebesar 0.7644. Hasil tersebut menunjukkan bahwa sub skala ini memiliki reliabilitas yang baik, karena berada di atas 0.7 (Kaplan dan Saccuzzo, 1993). Oleh karena itu, skala ini dapat dikatakan mampu mengukur derajat depresi, di mana individu mengalami perubahan dalam melakukan dan menghadapi aktivitas dalam kehidupan sehari-hari, seperti kehilangan minat untuk melakukan aktivitas yang menyenangkan.

\section{Teknik Analisis}

Analisis data kuantitatif dilakukan dengan cara memasukkan dan mengolah data yang diperoleh dari seluruh subjek penelitian dengan menggunakan program SPSS. Hal ini dimaksudkan untuk menghitung reliabilitas dan validitas alat tes, kemudian memperoleh gambaran mengenai tingkat kecemasan dan depresi subjek penelitian.

Interpretasi HADS dilakukan dengan cara menjumlahkan semua respon subjek sebagai total skor. Skor berkisar antara 0-3 untuk masing-masing item. Interpretasi untuk masing-masing skor adalah: skor 0, subjek tidak pernah memiliki pengalaman yang berkaitan dengan kecemasan dan depresi; skor $1=$ subjek kadang-kadang memiliki pengalaman yang berkaitan dengan kecemasan dan depresi; skor 2 = subjek sering memiliki pengalaman yang berkaitan dengan kecemasan dan depresi; skor $3=$ subjek selalu memiliki pengalaman yang berkaitan dengan kecemasan dan depresi.

Setelah menjumlahkan skor pada masing-masing item sesuai dengan jawaban yang diberikan subjek, maka diperoleh total skor untuk masing-masing sub skala, yaitu subskala anxiety (kecemasan) dan sub skala depression (depresi). Berikut merupakan interpretasi dari total skor pada masing-masing sub skala (Snaith, 2003). 
0-7 : Tanpa adanya gangguan yang berupa kecemasan atau depresi (Normal).

8-10 : Tahap munculnya sugesti pada masing-masing subskala (Borderline Abnormal).

11-21 : Mengindikasikan adanya kecemasan atau depresi (Abnormal).

\section{ANALISIS \& HASIL}

Data diperoleh dari 30 orang responden yang merupakan pasien Gagal Ginjal Kronis yang sedang menjalani terapi hemodialisis. Pada umumnya, responden membutuhkan waktu sekitar 5-7 menit dalam menyelesaikan keseluruhan item. Gambaran umum responden di bawah ini diperoleh dari data kontrol responden. Berikut penjelasan lebih lanjut mengenai gambaran umum responden.

Tabel 4. Komposisi Subjek Berdasarkan Jenis Kelamin

\begin{tabular}{lcc}
\hline \multicolumn{1}{c}{ Jenis kelamin } & Frekuensi & Prosentase \\
\hline Pria & 19 & $63 \%$ \\
Wanita & 11 & $37 \%$ \\
\hline Total & 30 & $100 \%$ \\
\hline
\end{tabular}

Berdasarkan Tabel 4, terlihat bahwa jumlah subjek pria lebih banyak hampir dua kali lipat dibandingkan dengan jumlah subjek wanita. Jumlah subjek pria sebanyak 19 orang, yaitu sekitar $63 \%$ dari keseluruhan subjek, dan jumlah subjek wanita adalah 11 orang, yaitu sekitar $37 \%$ dari keseluruhan subjek.

Tabel 5. Komposisi Subjek Berdasarkan Usia

\begin{tabular}{ccc}
\hline Usia & Frekuensi & Prosentase \\
\hline $18-40$ Tahun & 8 & $27 \%$ \\
$41-60$ Tahun & 21 & $70 \%$ \\
$61-65$ Tahun & 1 & $3 \%$ \\
\hline Total & 30 & $100 \%$ \\
\hline
\end{tabular}

Pada Tabel 5, terlihat bahwa jumlah subjek terbanyak berada pada rentang usia 40-60 tahun, yaitu sekitar 70 \% dari total subjek. Menurut Hurlock (2000) rentang usia 40-60 merupakan tahap dewasa menengah (Midle Adulthood). 8 orang subjek, yaitu sekitar $27 \%$ dari seluruh subjek penelitian berada pada rentang usia 18-40 tahun yang merupakan tahap usia dewasa awal (early adulthood). Satu orang subjek berada pada tahap dewasa akhir (late adulthood) dengan rentang usia antara 61-65 tahun. 
Tabel 6. Komposisi Subjek Berdasarkan Pekerjaan

\begin{tabular}{lcc}
\hline Pekerjaan & Frekuensi & Prosentase \\
\hline PNS & 10 & $33.3 \%$ \\
TNI & 3 & $10 \%$ \\
Mahasiswa & 1 & $3.3 \%$ \\
Karyawan Swasta & 1 & $3.3 \%$ \\
Bidan & 1 & $3.3 \%$ \\
Guru & 2 & $6.7 \%$ \\
Ibu Rumah Tangga & 9 & $30 \%$ \\
Purnawirawan TNI & 2 & $6.7 \%$ \\
Pensiunan PNS & 1 & $3.3 \%$ \\
\hline Total & 30 & 100.0 \\
\hline
\end{tabular}

Pada Tabel 6, terlihat bahwa pekerjaan yang paling banyak ditekuni oleh subjek penelitian adalah Pegawai Negeri Sipil (PNS) yang berjumlah 10 orang, yaitu sekitar $33.3 \%$ dari keseluruhan responden. 9 orang subjek yaitu sekitar $30 \%$ dari total responden bekerja sebagai ibu rumah tangga. 3 orang subjek (10 \%) merupakan anggota TNI. 2 orang subjek (6.7\%) bekerja sebagai guru. 2 orang (6.7 \%) merupakan Purnawirawan TNI. Serta terdapat masing-masing satu orang subjek untuk pekerjaan lainnya seperti mahasiswa, karyawan swasta, bidan, guru, dan pensiunan PNS.

Tabel 7. Komposisi Subjek Berdasarkan Lama Menjalani Terapi Hemodialisis

\begin{tabular}{lcc}
\hline \multicolumn{1}{c}{ Lama Menjalani Terapi } & Frekuensi & Prosentase \\
\hline$<1$ tahun & 8 & $26.7 \%$ \\
$1-<2$ tahun & 2 & $6.7 \%$ \\
$2-<3$ tahun & 9 & $30 \%$ \\
$3-<4$ tahun & 4 & $13.3 \%$ \\
$4-<5$ tahun & 1 & $3.3 \%$ \\
$6-<7$ tahun & 2 & $6.7 \%$ \\
$7-<8$ tahun & 1 & $3.3 \%$ \\
$10-<11$ tahun & 1 & $3.3 \%$ \\
$12-<13$ tahun & 1 & $3.3 \%$ \\
$>13$ tahun & 1 & $3.3 \%$ \\
\hline Total & 30 & 100.0 \\
\hline
\end{tabular}

Pada Tabel 7, Terlihat bahwa subjek penelitian yang menjalani terapi hemodialisis kurang dari 1 tahun berjumlah delapan orang, yaitu sekitar $26.7 \%$ dari jumlah seluruh subjek penelitian. Sembilan orang telah mejalani terapi hemodialisis selama 2 hingga kurang dari tiga tahun, yaitu sekitar $30 \%$ dari total subjek penelitian. Selain itu terdapat tiga orang subjek penelitian yang telah menjalani terapi hemodialisis selama lebih dari sepuluh tahun. Masing-masing diantaranya, satu orang telah menjalani terapi hemodialisis selama 
sepuluh tahun. Satu orang menjalani hemodialisis selama 12 tahun enam bulan dan satu orang lainnya telah menjalani terapi hemodialisis dalam jangka waktu 17 tahun.

Gambaran Penempatan Subjek berdasarkan Skor Total Masing-Masing Sub Skala Hospital Anxiety and Depression Scale (HADS)

Penempatan subjek dalam kategori kecemasan dan depresi, dapat dilakukan dengan cara menggunakan norma standar yang sudah ada.

Tabel 8. Kategori Sub Skala Kecemasan HADS (Snaith, 2003)

\begin{tabular}{llcccccc}
\hline \multirow{2}{*}{ Rentang } & \multirow{2}{*}{ Kategori } & \multicolumn{2}{c}{ Pria } & \multicolumn{2}{c}{ Wanita } & \multicolumn{2}{c}{ Total } \\
\cline { 3 - 8 } & & F & $\%$ & F & $\%$ & F & $\%$ \\
\hline $0-7$ & Normal & 14 & 46.67 & 8 & 26.67 & 22 & 73.33 \\
$8-10$ & Borderline Abnormal & 5 & 16.67 & 2 & 6.67 & 7 & 23.33 \\
$11-21$ & Abnormal & - & - & 1 & 3.3 & 1 & 3.33 \\
\hline Total & & 19 & 63.3 & 11 & 36.7 & 30 & 100 \\
\hline
\end{tabular}

Terlihat bahwa ada peringkat dalam frekuensi pada penggolongan kecemasan. Subjek dengan tingkat kecemasan yang tergolong abnormal hanya terdiri dari 1 orang subjek wanita, yaitu sekitar 3.3\% dari jumlah total seluruh subjek. Sedangkan subjek dengan tingkat kecemasan yang tergolong borderline abnormal berjumlah 7 orang, yaitu sekitar $23.3 \%$ dengan jumlah pria lebih banyak daripada wanita. Sedangkan subjek dengan kecemasan yang tergolong normal terdiri dari 22 orang, yaitu sekitar $73.33 \%$, dengan jumlah pria sebanyak 14 orang dan wanita 8 orang.

Tabel 9. Kategori Sub Skala Depresi HADS (Snaith, 2003)

\begin{tabular}{llcccccc}
\hline \multirow{2}{*}{ Rentang } & \multirow{2}{*}{ Kategori } & \multicolumn{2}{c}{ Pria } & \multicolumn{2}{c}{ Wanita } & \multicolumn{2}{c}{ Total } \\
\cline { 3 - 8 } & & F & $\%$ & F & $\%$ & F & $\%$ \\
\hline $0-7$ & Normal & 14 & 46.67 & 9 & 30 & 23 & 76.67 \\
$8-10$ & Borderline Abnormal & 5 & 16.67 & 2 & 6.67 & 7 & 23.33 \\
$11-21$ & Abnormal & - & - & - & - & - & - \\
\hline Total & & 19 & 63.3 & 11 & 36.7 & 30 & 100 \\
\hline
\end{tabular}

Pada Tabel 9 terlihat bahwa tidak terdapat subjek dengan tingkat depresi yang tergolong abnormal. Sedangkan subjek dengan tingkat depresi yang tergolong borderline abnormal berjumlah 7 orang, yaitu sekitar 23.3\% dengan jumlah pria 5 orang dan jumlah subjek wanita sebanyak 2 orang. Sedangkan subjek dengan tingkat depresi yang tergolong normal (dapat dikatakan tidak mengalami depresi) terdiri dari 23 orang, yaitu sekitar $76.67 \%$, dengan jumlah pria sebanyak 14 orang dan wanita 9 orang.

\section{DISKUSI}

Berdasarkan penelitian yang telah dilakukan, diperoleh beberapa hal yang patut mendapatkan perhatian. Hasil penelitian menunjukkan bahwa $73.33 \%$ subjek memiliki tingkat kecemasan yang tergolong normal, 
dalam arti $73.33 \%$ subjek tidak menunjukkan adanya gangguan kecemasan. $23.33 \%$ subjek tergolong borderline abnormal, pada subjek tersebut muncul sugesti-sugesti terkait kecemasan. Kemudian, $3.33 \%$ subjek tergolong dalam kategori abnormal, hal ini berarti adanya indikasi kecemasan pada diri subjek. Sementara itu pasien yang mengalami depresi dalam tingkat normal sebanyak $76.67 \%$, borderline abnormal $23.33 \%$ dan tidak ada yang mengalami depresi dalam kategori abnormal. Hasil tersebut mendukung teori yang ada dan sesuai dengan hasil penelitian sebelumnya yang menyatakan bahwa terdapat kecemasan dan depresi pada pasien penyakit kronis, dalam hal ini adalah pasien gagal ginjal kronis. Soehardjono (2006) berpendapat bahwa penyakit gagal ginjal kronis dapat digolongkan sebagai stressor, yaitu peristiwa yang menimbulkan stres pada seseorang. Subjek dalam penelitian ini, yaitu pasien gagal ginjal kronis, menilai sakitnya dan terapi hemodialisis sebagai sesuatu yang mengancam, atau membahayakan dirinya dan keluarganya. Ancaman yang dirasakan adalah kematian dan kehilangan kemampuan untuk melakukan aktivitas yang selama ini dilakukannya. Hidup bergantung pada mesin dialisis membuat individu memandang lemah kondisi tubuhnya dan berpikir bahwa ia tidak mampu lagi bekerja sehingga tidak dapat memenuhi kebutuhan hidupnya dan keluarga.

Kondisi di atas ternyata tidak dialami oleh sebagian besar pasien. Pasien yang telah mampu melakukan penyesuaian diri dengan penyakitnya beranggapan bahwa dengan menjalani terapi hemodialisis bukan berarti tidak lagi dapat beraktivitas. Sebagian besar pasien tetap beraktivitas seperti biasanya. Ada yang tetap menjalani profesinya sebagai guru, Pegawai Negeri Sipil (PNS), anggota TNI, mahasiswa, bidan, dan ibu rumah tangga. Dampak fisik seperti penurunan stamina, daya tahan tubuh, serta kekuatan fisik yang dimiliki memang dirasakan pasien. Pengaturan nutrisi yang ketat juga membuat pasien harus mengontrol pola makan dan minumnya, namun hal ini ternyata tidak dirasakan berat bagi mereka yang telah menyesuaikan diri dengan kondisinya, dalam hal ini, pasien sadar bahwa terapi hemodialisis dilakukan agar kondisi tubuhnya tetap stabil dan sehat.

Penerimaan pasien terhadap kondisinya ternyata dipengaruhi oleh beberapa faktor, diantaranya dukungan sosial yang diterima. Sebagaimana yang diungkapkan oleh Jatiputra (1996) bahwa individu yang memiliki dukungan sosial tinggi akan mengalami tingkat stress yang lebih rendah dibandingkan dengan individu yang memiliki dukungan sosial lebih rendah. Dukungan tersebut tidak hanya datang dari keluarga, melainkan juga datang dari dokter, perawat dan sesama pasien.

Pasien yang menjalani terapi hemodialisis memiliki perkumpulan, dalam forum tersebut pasien dapat berbagi pengalaman, saling memberikan dukungan dan motivasi kepada rekan-rekan lainnya. Selain itu, dalam forum, pasien bisa melihat pengalaman dari beberapa rekan lain yang masih dapat beraktivitas dengan normal meskipun harus menjalani terapi hemodialisis dua kali dalam seminggu. Hal ini membangkitkan semangat pasien untuk tetap beraktivitas, bekerja dan tidak putus asa dengan kondisinya.

Biaya terapi hemodialisis yang tergolong mahal juga menjadi persoalan, seperti yang diungkapkan oleh Soedarsono (2006) bahwa besarnya biaya hemodialisis juga menjadi beban tersendiri bagi individu yang menjalaninya. Hal ini ternyata disiasati oleh pasien dengan cara mengurus kartu Asuransi Kesehatan khusus bagi mereka yang berprofesi sebagai pegawai negeri. Mengurus surat keterangan keluarga miskin, bagi mereka yang tidak mampu, meminta bantuan dari yayasan seperti gereja dan lain sebagainya.

Pasien gagal ginjal kronis yang menjalani terapi hemodialisis sebenarnya bisa bertahan hidup lebih lama. Sebagaimana yang diungkapkan oleh Roesli (2006) bahwa di antara pasien ada yang sudah menjalani hemodialisis selama 15-20 tahun. Keberhasilan tidak hanya didukung oleh perawatan secara medis, tetapi juga oleh penyesuaian diri pasien terhadap kondisi sakit yang dideritanya. Perasaan cemas yang dirasakan 
pasien saat menjalani terapi hemodialisis memang sering ditemukan, namun dengan menjalani pengobatan, olahraga dan diet yang teratur, maka aktivitas tetap dapat dijalankan dengan normal. Pada kondisi ini, pasien perlu diarahkan untuk mengeluarkan respon-respon yang tepat untuk mengatasi kecemasannya, misalnya dengan memberikan informasi yang jelas kepada pasien mengenai manfaat terapi hemodialisis, berusaha meningkatkan pelayanan agar pasien merasa nyaman saat proses hemodialisis berlangsung. Dukungan keluarga dan sesama pasien lain juga diperlukan untuk meningkatkan motivasi pasien mengikuti terapi hemodialisis dan menghindari respon-respon yang dapat memperburuk situasi sehingga menimbulkan akibat yang lebih fatal.

\section{SIMPULAN \& SARAN}

\section{Simpulan}

Pada penelitian ini terlihat tingkat kecemasan dan depresi pada pasien gagal ginjal kronis yang menjalani terapi hemodialisis, yaitu $73.33 \%$ subjek memiliki tingkat kecemasan yang tergolong normal, $23.33 \%$ subjek memiliki kecemasan dalam kategori borderline abnormal, dan $3.33 \%$ tergolong normal. Sementara itu pasien yang mengalami depresi dalam tingkat normal sebanyak $76.67 \%$, borderline abnormal $23.33 \%$ dan tidak ada yang mengalami depresi dalam kategori abnormal. Hasil tersebut juga menunjukkan bahwa alat ukur Hospital Anxiety and Depression Scale yang telah diterjemahkan ke dalam bahasa indonesia tergolong valid dan reliabel, serta mampu mengukur tingkat kecemasan dan depresi pasien gagal ginjal kronis yang menjalani terapi hemodialisis.

\section{Saran}

\section{Saran kepada pasien}

1. Pasien dapat mencari informasi mengenai terapi hemodialisis, seperti manfaat, proses dan dampak yang ditimbulkan oleh terapi tersebut. Dengan demikian, pasien dapat memahami bahwa terapi yang diberikan kepadanya adalah untuk membantunya tetap sehat.

2. Pasien dapat mengikuti perkumpulan khusus bagi mereka yang menjalani terapi hemodialisis. Perkumpulan tersebut beranggotakan dokter, perawat dan pasien hemodialisis di hampir seluruh wilayah Jakarta. Dalam perkumpulan tersebut, pasien dapat berbagi pengalaman, mendapatkan informasi dari dokter dan perawat serta belajar dari pengalaman pasien lain bahwa mereka dapat beraktivitas dengan normal meskipun harus menjalani terapi hemodialisis.

3. Jika pasien merasa belum mampu mengatasi kecemasan, kekhawatiran dan perasaan sedih akibat terapi hemodialisis, maka pasien dapat berkonsultasi dengan psikolog.

\section{Saran kepada keluarga pasien}

Pihak keluarga hendaknya memiliki pengetahuan mengenai terapi hemodialisis, sehingga keluarga dapat memberikan penjelasan kepada pasien mengenai penyakit gagal ginjal kronis dan terapi hemodialisis, mereka juga diharapkan dapat membantu memberikan semangat dan motivasi kepada pasien untuk menjalani pengobatan secara teratur. 


\section{Saran kepada dokter dan perawat}

Dokter dan perawat dapat memberikan informasi yang jelas kepada pasien mengenai penyakit gagal ginjal kronis dan terapi hemodialisis, baik dari segi manfaat, proses, dan dampaknya bagi pasien. Selain melakukan kunjungan atau check up terhadap pasien, dokter dan perawat juga dapat berbicara dari hati ke hati dengan pasien, sehingga mereka dapat mengeluarkan keluh kesahnya selama menjalani terapi hemodialisis. Saran bagi penelitian selanjutnya.

1. Peneliti dapat melakukan wawancara dengan dokter atau perawat yang menangani pasien untuk mendapatkan gambaran mengenai respon dan kondisi psikologis yang dirasakan pasien saat mereka menerima vonis gagal ginjal kronis, vonis untuk melakukan terapi hemodialisis, dan kondisi psikologis selama pasien menjalani terapi.

2. Pemilihan subjek dapat lebih bervariasi, baik dari segi jenis kelamin, latar belakang pendidikan, pekerjaan dan kondisi sosial ekonominya.

3. Melakukan wawancara lebih mendalam, sehingga diperoleh gambaran menyeluruh mengenai kondisi psikologis pasien selama menjalani terapi hemodialisis.

\section{DAFTAR PUSTAKA}

Anastasi, A \& Urbina, S.(1997). Psychological Testing. ( $7^{\text {th }}$ Edition). New Jersey: Prentice Hall Inc.

Cronbach, L.J. (1984). Essential of Psychological Testing (4th Edition). New York: Harper \& Row, Publishers.

Desmond, D.M. \& McLachlan, M. (2005). The Factor Structute of the Hospital Anxiety and Depression Scale in Older Individuals with Acquired Amputations: a Comparison of Four Models Using Conformatory Factor Analysis. International Journal of Geriatric Psychiatry; 20: 344-349. Copyright: John Wiley \& Sons.

Downing-Orr, K. (2000). Burn out and Blue: The Essential Guide to Help You Through Depression. London: Thorsons.

Flint, A.J. \& Sandra, L.R. (2002). Factor Structure of Hospital Anxiety and Depression Scale in Older Patient with Major Depression. International Journal of Geriatric Psychiatry; 17: 117-123. Copyright: John Wiley \& Sons.

Hurlock, E.B. (2000). Psikologi Perkembangan: Suatu Pendekatan Sepanjang Rentang Kehidupan. Terjemahan. (edisi kelima). Jakarta: Erlangga.

Jatiputra, I. (1996). Psikologi Kesehatan. Makalah disampaikan dalam Seminar Mencari Makna Hidup, Jakarta, 14 Desember 1996.

Kaplan, R. \& Saccuzzo, D. (1993). Psychologycal Testing-Principles, Aplication, and Issues. Pacific Grove, CA: Brooks/Cole. Publishing Company.

Mc. Dowel, I. \& Newell, C. (1996). Measuring Health: A Guide to Rating Scales and Questionnaire (2 ${ }^{\text {nd }}$ ed). New York: Oxford University Press.

Mykletun, A., Stordal, E \& Dahl, A.A. (2001). Hospital Anxiety and Depression (HAD) Scale: Factor Structure, Item Analysis and Internal Consistency in a Large Population. British Journal of Psychiatry; 179: 540-544. 
Nunnaly, J.C. \& Bernstein, I.H. (1994). Psychometric Theory. ( $3^{\text {rd }}$ ed). New York: McGraw-Hill.

Peterson, J.C., Adler, S., Burkart, J.M., et al. (1995). Blood Pressure Control, Proteinuria, and the Progression of Renal Disease: The Modification of Diet in Renal Disease Study. Annals of Internal Medicine; 123(10): 754-762

Snaith, R.P. (2003). The Hospital Anxiety and Depression Scale. Health and Quality Life Outcomes; 1:29. Licensee Biomed Central Ltd.

Soehardjono. (2006). Proteinuria Pada Penyakit Ginjal Kronik: Mekanisme dan Pengelolaannya. Jakarta: Divisi Ginjal Hipertensi. Departemen Penyakit Dalam FKUI/RS Dr. Ciptomangunkusumo.

Taylor, S. E. (1999). Health Psychology. (4 ${ }^{\text {th }}$ ed). Boston: McGraw-Hill.

Wolman, B \& Stricker. (1994). Anxiety and Related Disorders: A Handbook. New York: John Wiley \& Sons.

\section{Internet}

Lumenta, N . A. (2003). Konsultasi: Bisakah Cuci Darah Dihindari. http://www.sinarharapan.co.id./iptek/ kesehatan/2003/0704/ kes2.html. (19-06-2006)

Roesli, R.M.A (2006). Gagal Ginjal. http://totalwellness.blogsome.com/2006/04/27/ gagal-ginjal. (19-062006)

, (2006). Mari Menjaga Ginjal Kita. http://www.dinkesjatim.go.id/ berita-detail .html_news_id. (19-06-2006) 